\title{
Acute toxicity of Brosimum gaudichaudii Trécul. root extract in mice: determination of both approximate and median lethal doses
}

\section{Luiz Carlos da Cunha,* José Realino de Paula, Vinícius Augusto de Sá, Marcos Evaristo da Paixão e Amorim, Isabel Cristina Medeiros Barros, Luiz Augusto Batista Brito, Nusa da Silveira}

\author{
Universidade Federal de Goiás, Faculdade de Farmácia, Núcleo de Estudos e Pesquisas Tóxico- \\ Farmacológicas, Av. Universitária com $1^{a}$ Avenida, Qd. 62, $2^{\circ}$ Andar, Sala 41, Setor Universitário, \\ 74605-220 Goiânia-GO, Brazil
}

\begin{abstract}
RESUMO: “Toxicidade aguda de extrato de raízes de Brosimum gaudichaudii Trécul. em camundongos: determinação da dose letal aproximada e da dose letal mediana”. O Brosimum gaudichaudii Trécul. (BG) família Moraceae, é largamente distribuído nas regiões de cerrado do Brasil e é popularmente conhecido como "mamacadela" e possui, na sua composição química, furocumarinas fotossensibilizantes. O principal uso terapêutico do BG é no tratamento do vitiligo, uma doença despigmentante da pele com prevalência de aproximadamente $1-2 \%$ da população mundial. Há um produto no mercado $\left(\right.$ Viticromin $^{\circledR}$ ), que é comercializado com tal finalidade, havendo poucos dados disponíveis acerca da toxicidade experimental, ao lado de eficácia clínica comprovada. Portanto, o desenvolvimento de estudos de toxicidade pré-clínica foi proposto (dose letal aproximada, DLA e dose letal mediana, DL50) para o exsudato da raiz de BG em animais de laboratório. Foram utilizados camundongos machos, albinos, pesando entre 25 e 30 $\mathrm{g}$, em boas condições sanitárias, recebendo água e ração ad libitum. O pó de BG foi suspenso em solução salina $0,9 \%$ com $0,5 \%$ de cremofor e administrado p.o. (gavage) e intraperitonealmente. A DL50 foi obtida através do método de regressão linear de Lichtfield \& Wilcoxon (1949), utilizando um software de domínio público. Foram formados 6 grupos de 10 animais para cada via de administração, incluindo grupo controle, e o número de mortes foi observado durante 14 dias; o grupo controle recebeu uma emulsão de solução salina $0,9 \%$ com $0,5 \%$ de cremofor. Antes de estabelecer a DL50 e visando reduzir o número de animais utilizados, determinou-se a DLA, utilizando 1 animal por dose (a próxima dose $50 \%$ maior do que a dose anterior), até identificar a dose letal para 1 animal. Assim, a DLA p.o. foi de $3750 \mathrm{mg} / \mathrm{kg}$ e a DLA i.p., $2920 \mathrm{mg} / \mathrm{kg}$. A DL50 p.o. foi de $3517,54 \mathrm{mg} / \mathrm{kg}$ e a DL50 i.p. foi $2871,76 \mathrm{mg} / \mathrm{kg}$. O produto foi considerado possuir baixa toxicidade, considerando apenas uma dose neste ensaio de toxicidade aguda.
\end{abstract}

Unitermos: Brosimum gaudichaudii, Moraceae, toxicidade aguda.

\begin{abstract}
The Brosimum gaudichaudii Trécul. (BG) Moraceae, with a high frequency in regions of the Brazilian cerrado (shrubland) and popularly known as "mamacadela", holds photosensitizing furocoumarins. The BG's main therapeutic use is the treatment of vitiligo, a skin depigmentation disease that takes hold of approximately 1-2 \% of the world population. There is one product on the marketplace $\left(\right.$ Viticromin $\left.^{\circledR}\right)$, for which there is no scientific research available about its experimental toxicity, in spite of its proven clinical efficacy. Therefore, the development of acute pre-clinical toxicity trials has been proposed (approximate lethal dose, ALD, and median lethal dose, LD50) of the BG root exsudate in laboratory animals. Male, albino mice weighing between 25 and $30 \mathrm{~g}$, in good sanitation conditions have been used. The mice received water and food ad libitum. The BG powder was mixed in $0.9 \%$ saline solution and $0.5 \%$ cremophor and was administered po and ip. The LD50 was obtained through the Lichtfield and Wilcoxon (1949) method. A public domain software was used for the calculations. Ten mice/dose were used - 6 groups for each administration via, including the control group - and the number of deaths within up to 14 days was considered; the control group received an emulsion made up by 0.9 saline solution and $0.5 \%$ cremophor. Before establishing the LD50 and aiming at reducing the number of animals used, the DLA was determined when 1 animal per dose was used (the next dose always $50 \%$ higher than the previous dose), until identifying the dose that led to the death of 1 animal. Thus, the DLA po was $3750 \mathrm{mg} / \mathrm{kg}$ and the DLA ip, $2920 \mathrm{mg} / \mathrm{kg}$. The LD50 po was $3517.54 \mathrm{mg} /$ $\mathrm{kg}$ and the LD50 ip was $2871.76 \mathrm{mg} / \mathrm{kg}$. The product was considered as of being of low toxicity, taking into account only the single dose acute toxicity.
\end{abstract}

Keywords: Brosimum gaudichaudii, Moraceae, acute toxicity. 


\section{INTRODUCTION}

Since ancestral times, medicinal plants have been largely used by mankind for preventing and curing illnesses. Along thousands of years of successful and unsuccessful experiences, knowledge has been accumulated about both their benign and malign effects. Today, many illnesses can be treated by means of this natural resource. Beginning with the true laboratory provided by nature, it has been possible to obtain a good degree of pharmaceuticals that are presently used, such as: morphine (poppies), salicylic acid (willow), cocaine (coca leaf), atropine (belladonna), digoxine (foxglove), quinine (cinchona or quinine-tree), caffeine (coffee), neuromuscular blocking agents (curare), among others.

The employment of pharmaceutical technology has provided for the diffusion of industrialized drugs as a predominant therapeutic resource, but very costly for patients. Therefore, the social and economic conditions in force, especially in third world countries, have led the lower classes to search for much cheaper and relatively safe therapeutic alternatives such as, for example, medicinal herbs.

At the same time, in recent years a "return to the origins" has been observed, provided by the need for new drugs, with lower toxicity levels and lower costs. The pharmaceutical industry has encouraged this trend, as it recognizes an opportunity to provide the marketplace with a pharmacotherapeutic arsenal with scientifically proven alternatives.

A detailed study of natural products becomes necessary in order to discover its potential collateral effects and main recommendations. Thus, the population will be offered additional and accessible options in its fight against the so many illnesses. Additionally, medicinal herbs constitute the main hope in the treatment of illnesses whose causes are unknown and that very often remain without treatment. Estimates are that our planet contains about 250,000 botanic species. Of these, only an expressionless percentage has been investigated as to its pharmacology and toxicology.

Encouraging research about natural products would not only benefit the poor population, but also the Brazilian health system as a whole, as it would reduce the demand for public services, since it encourages oriented self-medication, of a much lower cost and usually quite low risk (Ribeiro et al., 2005; Silva et al., 2006; VeigaJunior, 2008; Carvalho et al., 2008)

The roots and the lower part of the stem of the Brosimum gaudichaudii Trécul. (BG), a plant of the Moreaceae family, frequent in the cerrado region and Northeast of Brazil, which is popularly known as "mamica de cadela", "mamacadela" and "algodão" (cotton), are employed by popular medicine in the fight against vitiligo and skin deseases (Macedo \& Ferreira, 2004; Agra et al., 2007 and 2008). Its fruit, of a yelloworange color, is chewed as chewing gum, due to the latex it contains and due to its flavor, while the powder obtained by scrapping the roots is used as a fragrance (Hoehne, 1946).

Usually plants used for fighting vitiligo (leucomelanodermia), contain furocoumarins. Furocoumarins are of a broad spectrum of application in the treatment of leucomelanodermias, with photosensitizing activity upon the skin (Dean, 1963; Alchorne, 2001). Many studies have been carried out about this type of activity of the furocoumarins (Pozetti, 1966; Azambuja, 1981; Parsad et al 1998; Jimbow, 1998). It is known that "all fluorescent substances found in nature, whatever the chemical function they belong to, are active therapeutically and pharmacologically without exception" (Pozetti, 1969).

We wish to highlight that vitiligo is made up by achromic spots, of irregular shape, clear contours, sometimes of symmetric disposition, other times distributed by chance, that occur in any part of the tegmen, followed or not by depigmentation of hair, with a 2 to 3 times larger incidence on the female gender than on the male gender; it affects 1 to $2 \%$ of the population in general, $30 \%$ of all cases being of hereditary origin (Auad, 1973; Lerner \& Nordlund, 1977; Azambuja, 1981; Alchorne, 2001). The treatment of vitiligo has been made and/or attempted through the use of several substances and/or mixtures of substances, such as bergamot essence at $20-25 \%$, oral and local corticosteroids, adrenocorticotropic hormone (ACTH) and the placenta extract (Alchorne, 2001). In 1947, El-Mofty launched a treatment based on the use of photosensitizing substances obtained from Ammi majus Linn, which contains amoidine-8-methoxypsoralen, amoidine-8-isoamylinpsoralen and bergapten as active principles, that depended on exposure to sun rays in order to promote re-pigmentation (Azambuja, 1981; Sampaio et al. 1983).

The employment of 8-methoxypsoralen and trimethoxypsoralen, followed by exposition to ultraviolet light (photochemotherapy with UV-A, PUVA) of benzoquinone monobenzylic ether are being studied nowadays and since the 1980's for repigmentation (Martins et al., 1974; Azambuja, 1981; Parsad et al. 1998; Jimbow, 1998).

As has already been mentioned, in our region the roots and the lower part of the stem of Brosimum gaudichaudii Trécul. have been used as a source of photosensitizing furocoumarins. In this plant, a few substances - furocoumarinic derivates, such as: xanthyletine, bergapten, psoralen, luvangentine and the gaudichaudine (Figure 1) - have been isolated and identified, all of which have photosensitizing capability (Pozzetti, 1969; Anderson \& Voorhees, 1980; Vieira et al., 1997). Synthetic similar products have already been found in the pharmaceutical market for use in the formulation of world-class drugs for the treatment of vitiligo and other depigmentating skin diseases.

Rev. Bras. Farmacogn. Braz J. Pharmacogn 18(4): Out./Dez. 2008 
<smiles>O=c1ccc2cc3ccoc3cc2o1</smiles>

Psoralen<smiles>CC1(C)C=Cc2cc3ccc(=O)oc3cc2O1</smiles>

xantylethyn<smiles>COc1c2ccoc2cc2oc(=O)ccc12</smiles>

bergapten<smiles>COc1c2c(cc3ccc(=O)oc13)C=CC(C)(C)O2</smiles>

luvagenthyne<smiles>Cc1oc2cc3oc(=O)ccc3cc2c(=O)c1C</smiles>

guaudichaudine

Figure 1. Phytochemical profile of the Brosimum gaudichaudii Trécul. roots, highlighting a few furocoumarinic active principles.

There is a commercial product on the marketplace for the treatment of vitiligo (Viticromin AUAD Química), the main active component of which is made up by the lower part of the stem and of the roots of mamacadela (Brosimum gaudichaudii), that are harvested, dried, peeled, ground and prepared in pharmaceutical forms for internal (as tablets) and external (as creams and solutions) use (DEF, 2000).

The recommended dose of Viticromin ${ }^{\circledR}$ to be employed is 2 to 4 tablets for at least 6 months to 1 year and gradual exposure to sunlight ( 5 - 60 minutes). After a couple of weeks of oral ministration and exposure to the morning sun, the topical treatment with hydro-alcoholic solution or cream and exposure to the afternoon sun is started. Inadvertent exposure to the sun should be avoided, due to the risk of burning (Sampaio et al., 1983; Azambuja, 1981).

The tablets, prepared with the vegetal raw material (root bark), hold $80 \%(\mathrm{p} / \mathrm{p})$ of root powder of Brosimum gaudichaudii (400 mg in $500 \mathrm{mg}$ qsp. excipient), while the cream contains $20 \%$ (p/p) of powder (6 $\mathrm{g}$ in $30 \mathrm{~g} q s p$ excipient) and the solution contains a $20 \%$ concentration $(\mathrm{p} / \mathrm{v})(12 \mathrm{~g}$ powder in $60 \mathrm{ml} q s p$ excipient). The differences in concentration between the product for internal use and the products for external use must reflect eventual losses during the pharmacokinetic route of the active principles, in the stages of absorption, distribution, biotransformation and excretion, until they reach the action site, which corresponds to the area of epidermis suffering the depigmentation characteristic of the several forms of manifestation of vitiligo.

Although Viticromin ${ }^{\circledR}$ is registered since 1968 at the Brazilian Ministry of Health and in spite of the existence of some clinical studies that demonstrate an up to $100 \%$ efficacy in terms of repigmentation in some cases (Azambuja, 1981; Anderson et al. 1980; Auad, 1973), for the long run treatment of vitiligo (5 to 18 months) there is no study about the pre-clinical and clinical toxicity (acute, sub-acute and chronic) and pharmacology. First of all, it is necessary to assess the acute toxicity of Brosimum gaudichaudii. in mice, by determining the approximate lethal dose (ALD) and the median lethal dose (LD50), as a part of regulatory requirements (Brasil, 1994; Brasil, 2000; Brasil, 2004).

\section{MATERIAL AND METHODS}

All botanical material for the toxicity study was provided by AUAD Química Ltda., with a certificate of origin and quality (Batch $n^{\circ} .515 / 00$ ), part of this material being deposited at our laboratory.

Of the Brosimum gaudichaudii - BG (Figure 2.1), we have used the root bark (Figure 2.2) still fresh and duly clean, which was crushed and pressed in order to obtain the exsudate that, later on, was dried in a stove with hot air ventilation.

In macroscopic terms, the bark presents itself in either curved or plane fragments, not rolled in, of varied length and width, 5 to $10 \mathrm{~mm}$ in thickness. The external surface is made up by a brown rugose suber. The stem bark surface presents itself even more rugose and dark. Once the suber is removed, the light brown cortical parenchyma, somewhat striped in the longitudinal direction, appears. The internal surface is light brown and fibrose. It has characteristic odor and flavor. When the root bark is ground, sifted and taken into the oven for drying, initially at temperatures between $60{ }^{\circ} \mathrm{C}$ to $80{ }^{\circ} \mathrm{C}$, and later at temperatures between $40{ }^{\circ} \mathrm{C}$ and 60 ${ }^{\circ} \mathrm{C}$ until reaching constant weight, a powder is obtained. This powder, in microscopic terms, presents itself as pieces in varied shapes and sizes, in the amber color, semi-transparent when observed under the microscope 
under direct light. When observed under a diffuse light or with the naked eye, it presents itself as a very fine powder, of characteristic odor and acrid flavor. This raw material, rich in bergapten and psoralen, is used in the manufacturing of the Viticromin ${ }^{\circledR}$ drug. The dosage methodology of the bergapten and psoralen biomarkers in the used exsudate is in a development stage.

For determining the acute toxicity of $\mathrm{BG}$ (approximate lethal dose, ALD, and average lethal dose, LD50), 130 albino male mice were used, weighing between 35 and $45 \mathrm{~g}(39.9 \pm 4.8$; Median: 40.6), and in good sanitation conditions, receiving autoclaved water and food ad libitum, confined in polypropylene cages in an environment with a 12-hour light-dark cycle and temperatures oscillating between $22-26^{\circ} \mathrm{C}$. Twelve hours before the experiment started, animals were submitted to food fasting, and the food returned two hours after the drug was ministered to each animal.

Emulsions in ultrasound bath (saline + cremophor at $0.5 \% \mathrm{v} / \mathrm{v}$ ) were prepared with the $\mathrm{BG}$ powder, in concentrations sufficient for ministering the po dose (gavage feeding) and ip dose in constant volume of $0.1 \mathrm{ml} / 10 \mathrm{~g}$ of the animals living weight; initially, doses of $500 \mathrm{mg} / \mathrm{kg}$ were used for the ALD study, with $50 \%$ increases, up to the maximum value of the lethal dose for 1 animal (ALD) through the per oral (po) and intraperitoneal (ip) vias - in spite of the fact that this last via is not used for therapeutic purposes and is not the most appropriate for the best dissolution of the BG extract. $1 \mathrm{ml}$ polypropylene syringes subdivided at every $0.1 \mathrm{ml}$ and with a needle adapted for gavage feeding were used.

For determining LD50, the mice were divided into 2 large groups, according to the administration via: per oral and intraperitoneal. Each one of the groups was subdivided into 6 sub-groups of 10 animals each:
1 control sub-group (salina + cremophor at $0.5 \%, p o$ ) and 5 test sub-groups, which have received estimated increasing doses, starting from the po $(1400,2000$, $3000,4000$ and $5000 \mathrm{mg} / \mathrm{Kg})$ and $i p(1000,1500,2250$, 3500 and $5000 \mathrm{mg} / \mathrm{Kg}$ ) ALD of BG.

Signs of general toxic effects, such as effects upon locomotion, behavior (agitation, drowsiness, reduced activity), respiration, salivation, watering of eyes, hemorrhage, consistency of feces, hair standing on end, cyanosis of the tail and the mortality of the animals were monitored at regular intervals during the first 24 hours and after that, on a daily basis, for a 14-day period (Malone \& Robichaud, 1962).

The animals that died during the experiment were examined macroscopically, aiming at identifying eventual morphological alterations. Some organs (liver, heart, small intestine, stomach, lung, kidney, spleen, brain) were forwarded for histopathological study. At the end of the experiment, all surviving animals were sacrificed by means of inhalation of chloroform and were macroscopically examined.

The LD50 and its confidence interval were calculated according to probit methods, with the support of a public domain statistical program based on the traditional Lichtfield \& Wilcoxon (1949) method by means of linear regression techniques.

\section{RESULTS}

Oral administration of BG root exsudate induced animals to death, proportionally to the administered doses (Table 1). The approximate lethal po dose was $3750 \mathrm{mg} / \mathrm{kg}$, and through the ip via, 2900 $\mathrm{mg} / \mathrm{kg}$. Logarithms and probits were determined for each dose, aiming at calculating the median lethal dose (DL50), which has resulted in $3517.54 \mathrm{mg} / \mathrm{kg}$ (po;

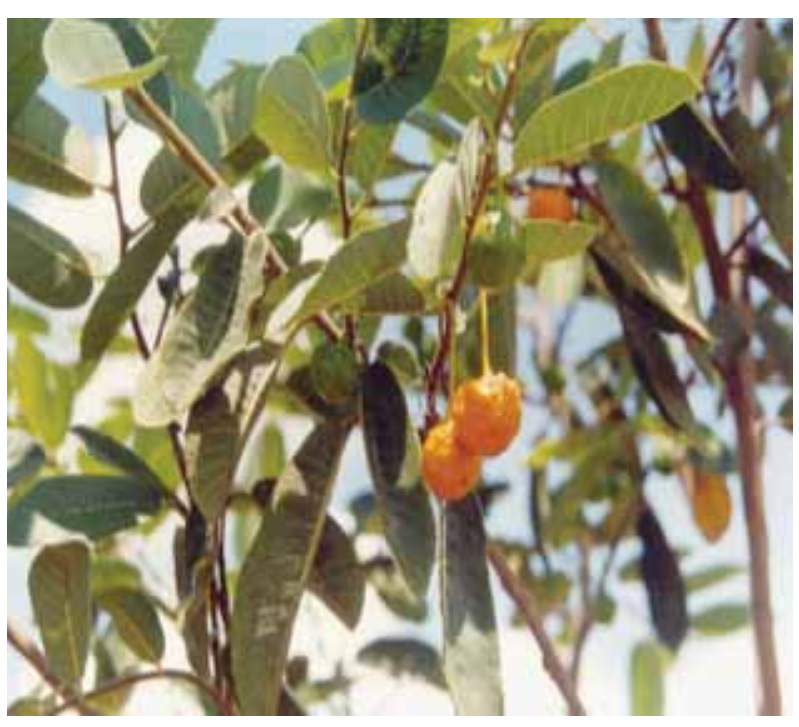

Figure 2.1. Macroscopic aspect of the fruit and leaves of Brosimum gaudichaudii Trécul. (mamacadela).

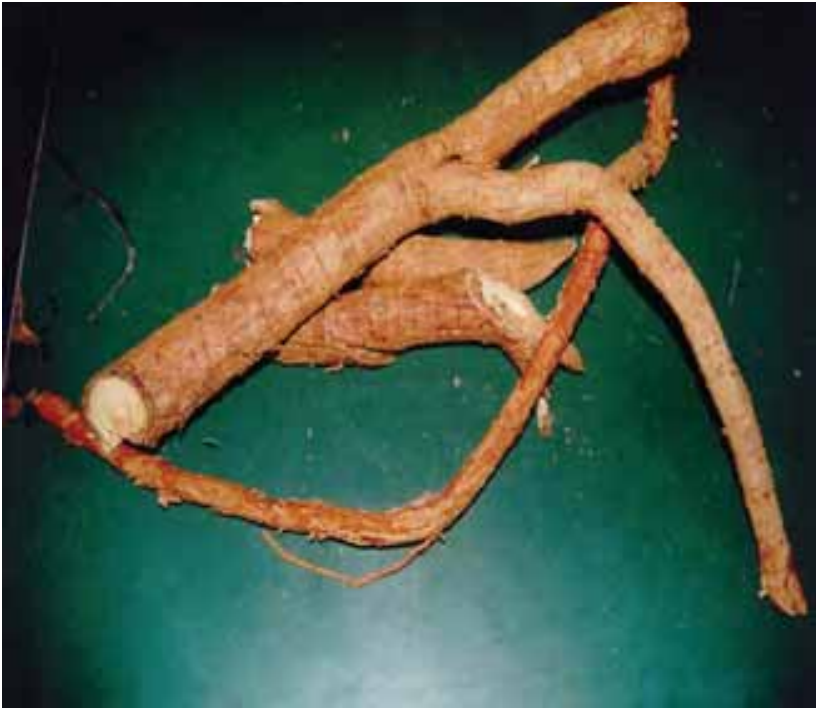

Figure 2.2. Macroscopic aspect of the roots of Brosimum gaudichaudii Trécul. (mamacadela). 
IC95\% 3094.25 - $3998.74 \mathrm{mg} / \mathrm{kg}$ ). The ip DL50 was calculated by the same procedure, producing a value of $2871.76 \mathrm{mg} / \mathrm{kg}$ (IC95\% $2389.69-3451.07 \mathrm{mg} / \mathrm{kg}$ ) (Table 2).

The $2000 \mathrm{mg} / \mathrm{kg}$ dose is established as a dose ceiling of the plant extract for the determination of DL50 because, above this value, the result obtained may be considered out of the product's standards for therapeutic use and, therefore, unrealistic, without significance under the conditions foreseen for the its use (Brasil, 1996; WHO, 1993; Lapa et al., 1983).

Some signs related to adverse and/or dosedependant toxic effects of the $\mathrm{BG}$ exsudate have been noticed, that is: in doses up to $2000 \mathrm{mg} / \mathrm{kg}$, about $40 \%$ of all animals presented diarrhea and abundant defection. In higher doses (up to $5000 \mathrm{mg} / \mathrm{kg}$ ), in addition to diarrhea in all animals, some of them have shown signs of drying of the ocular mucosa (dry eye) and eyelid occlusion, ocular hemorrhage, epistaxis, weight loss and tachypnea. The seriousness of the intoxication signs was dose-dependant (Table 3). Deaths occurred from the 24 hour period until 5 days after the administration. The higher doses have led to lethality in a much shorter period of time.

A deviation of the hepatic sinusoids in the 3, 4 and 5 test groups were noticed in $75 \%$ of all animals and in $60 \%$ of the animals of the control group (po group), what could also be explained as a consequence of the acute effects of the inhalation of chloroform, the same fact having occurred, in similar proportions, to the ip group.

A difference in the amount of hemosiderin

Table 1. Mortality of male mice after intra-gastric administration of Brosimum gaudichaudii root exsudate (Control group: 10 male animals; no death).

\begin{tabular}{ccccccc}
\hline Group & Dose $(\mathrm{mg} / \mathrm{kg})$ & Log dose & $\begin{array}{c}\text { Number of } \\
\text { animals }\end{array}$ & Response & $\begin{array}{c}\text { Expected } \\
\text { Frequency }\end{array}$ & Probit \\
\hline 1 & 1400 & 3.146128 & 10 & 0 & 0.001435 & 1.373116 \\
2 & 2000 & 3.301030 & 10 & 0 & 0.131166 & 2.777255 \\
3 & 3000 & 3.477121 & 10 & 3 & 2.654829 & 4.373467 \\
4 & 4000 & 3.602060 & 10 & 7 & 6.935715 & 5.505999 \\
5 & 5000 & 3.698970 & 10 & 9 & 9.168910 & 6.384459 \\
\hline
\end{tabular}

Results: DL50 = 3517.54 mg/Kg; $\log (\mathrm{DL} 50)=3.546239$; Weighed linear regression: probit $=9.065 \mathrm{x} \log ($ Dose $)-27.146$; Standard error of $\log ($ DL50 $)=2.841083 * 10^{-2}$; Inclination $=2.424905 ;$ IC95\% of DL50 $=3094.25-3998.74 \mathrm{mg} / \mathrm{Kg}$; Degree of Freedom $=0$; QUI-SQUARE test not performed.

Table 2. Mortality of male mice after ip administration of the Brosimum gaudichaudii root exsudate (Control group: 10 male animals; no death).

\begin{tabular}{ccccccc}
\hline Group & Dose $(\mathrm{mg} / \mathrm{kg})$ & Log dose & $\begin{array}{c}\text { Number of } \\
\text { animals }\end{array}$ & Response & $\begin{array}{c}\text { Expected } \\
\text { Frequency }\end{array}$ & Probit \\
\hline 1 & 1000 & 3.000000 & 10 & 0 & 0.026565 & 2.212597 \\
2 & 1500 & 3.176091 & 10 & 1 & 0.430763 & 3.283948 \\
3 & 2250 & 3.352182 & 10 & 2 & 2.595607 & 4.355299 \\
4 & 3500 & 3.544068 & 10 & 6 & 6.994242 & 5.522745 \\
5 & 5000 & 3.698970 & 10 & 10 & 9.285638 & 6.465177 \\
\hline
\end{tabular}

Results: DL50 = 2871.76 mg/Kg; $\log ($ DL50) = 3.458148; Weighed linear regression: probit $=6.084062 \times \log ($ Dosis $)-16.039583$; Standard error of $\log ($ DL50 $)=4.071824 * 10^{-2}$; Inclination $=1.442219 ;$ IC95\% de DL50 $=2389.69-3451,07 \mathrm{mg} / \mathrm{Kg}$; Degree of Freedom $=0$; QUI-SQUARE test not performed.

Table 3. Clinical signs observed in mice after the po administration of Brosimum gaudichaudii extract.

\begin{tabular}{cccl}
\hline Group & Dose $(\mathrm{mg} / \mathrm{kg})$ & $\begin{array}{c}\text { Number of } \\
\text { animals }\end{array}$ & \multicolumn{1}{c}{$\begin{array}{c}\text { Clinical signs observed } \\
\text { (no. of cases) }\end{array}$} \\
\hline 1 & 1400 & 10 & Diarrhea (4) \\
2 & 2000 & 10 & $\begin{array}{l}\text { Diarrhea (4) } \\
\text { Diarrhea (10), dilated pupil, ocular lesion with hemorrhage, half shut and dry } \\
\text { eyes (4) }\end{array}$ \\
4 & 3000 & 10 & Diarrhea (10), semi-shut and dry eyes (4) \\
5 & 4000 & 10 & Diarrhea (10), dyspnea (2) and weight loss (2). \\
\hline
\end{tabular}


was noticed in the spleen of the test group animals, in comparison to the control group. In test groups 3,4 and 5,70\% of all animals demonstrated an increase in hemosiderin in the spleen, while only $10 \%$ of the control group showed the same effect, which also happened in the ip group. Some kidney tissue cuts demonstrated the occurrence of vessel dilation and hemorrhage. The influence of such alterations upon the death cause must be taken into account in sub-acute and chronic toxicity tests.

The increase of hemosiderin was the only statistically meaningful difference between the test and control group animals in the histopathological study. The presence of a high amount of hemosiderin in the spleen indicates it suffered previous hemorrhage, attributed to the high dose of the applied product. The observed hemosiderin is the result of the destruction of red blood cells in this organ, liberating its content. Thus, when the hematoxylin-eosin technique is employed the coloring becomes yellowish.

The other analyzed innards presented a normal appearance, demonstrating no alteration caused by the product applied to the animals.

\section{DISCUSSION}

As the use of phytotherapeutical products is a common practice in our country and considering that several botanical species present toxic effects, establishing the experimental toxicity can contribute to avoiding or preventing organic damage (Lapa et al., 1983), in addition to contribute to the determination of doses for the elaboration of the dose-response profile in pharmacological studies (Brito, 1994; OECD, 1999).

In the case of the botanical species under study, there are no citations in literature about the toxicity of $B G$ root bark powder. It was suspected to be of low acute toxicity, due to its extensive and intensive traditional use by the populations of cerrado regions (Ortêncio, 1997). Such hypothesis - of low oral acute toxicity - was partially confirmed by the present study. When Tables 1 and 2 and the DL50, as well as the high ALD value, are observed $(>2000 \mathrm{mg} / \mathrm{kg})$, and applying the rules established by the Brazilian Ministry of Health (Brasil, 1996; Brasil, 2000; Brasil, 2004) and by the Organisation for Economic Co-operation and Development (OECD, 1999), DL50, whenever above $2000 \mathrm{mg} / \mathrm{kg}$ classifies the product as being of low acute toxicity and would hardly be therapeutically useful above such dose.

Additionally, among the several botanical phytotherapeutical species revised, it was observed that DL50 values are very variable, from the very toxic such as garlic oil and extract (Allium sativum; DL50, $100 \mathrm{mg} / \mathrm{kg}$ in mice $p o$ ) up to $731 \mathrm{mg} / \mathrm{kg}$ for pomegranate (Punica granatum) (Joseph et al., 1989; Vidal et al., 2003), demonstrating a high level of safety for the BG exsudate, when the fixed dose acute toxicity study is considered.

The daily therapeutic dose of BG Trécul. root exsudate for human adults is $400 \mathrm{mg}$ twice a day (800 $\mathrm{mg}$ ). Considering a $80-\mathrm{kg}$ individual, the daily dose per body weight would be of $10 \mathrm{mg} / \mathrm{kg}$, completely dissonant from the value obtained for ALD po (375 times higher than the standardized therapeutic dose) and ip (290 times the therapeutic dose) and for DL50 po (351 times higher than the therapeutic dose) and ip (287 times the therapeutical dose) of the aforementioned product, demonstrating the low acute toxicity of the Brosimum gaudichaudii root bark extract.

Nevertheless, toxicity studies of repeated dose (sub-acute and chronic) are required in order to assess how far organic systems may be affected when animals are treated in the medium and long run, since the product is recommended for lengthy treatments.

\section{ACKNOWLEDGMENTS}

We are grateful to the Conselho Nacional de Desenvolvimento Científico e Tecnológico (CNPq, Brazil) and the Auad Química (Pharmaceutical Industry, Brazil) for the financial research support.

\section{REFERENCES}

Agra MF, França PF, Barbosa-Filho JM 2007. Synopsis of the plants known as medicinal and poisonous in Northeast of Brazil. Rev Bras Farmacogn 17: 114140

Agra MF, Silva KN, Basílio IJLD, França PF, Barbosa-Filho JM 2008. Survey of medicinal plants used in the region Northeast of Brazil. Rev Bras Farmacogn 18: 472-508.

Alchorne MMA 2001. Discromias 176-177, In: Prado F.C., Ramos J. \& Valle, J.R. Atualização Terapêutica 2001 - Manual Prático de Diagnóstico e Tratamento, $20^{\mathrm{a}}$ Edição, Ed. Artes Médicas, São Paulo-SP. 1630p.

Anderson TF, Voorhees JJ 1980. Psoralen photochemotherapic of cutaneous disorders. Ann Rev Pharmacol Toxicol 20: $235-257$

Auad A 1973. Diagnose e Terapêutica do Vitiligo. Atualização Médica-Caderno de Dermatologia, 85-88.

Azambuja R 1981. Tratamento do vitiligo. Brasília Médica 18: 69-73.

Brasil 1994. Portaria $n^{\circ} 123$, de 19 de outubro de 1994 - Norma técnica para registro de Fitoterápicos. Secretaria Nacional de Vigilância Sanitária, Ministério da Saúde. (Administrative Rule $n^{\circ} 123$, of October 19th, 1994 - Technical rule for the registration of Phytotherapeutical Products. National Secretariat for Sanitary Surveillance, Ministry of Health.)

Brasil 1996. Portaria $n^{\circ} 116$, de 8 de agosto de 1996. DOU 12/08/96 - Dispõe sobre normas para estudo da toxicidade de produtos fitoterápicos. Secretaria Nacional de Vigilância Sanitária, Ministério da Saúde. (Administrative Rule $n^{\circ} 116$, of August 8th, 1996, Official Gazette 12/08/96 - Sets forth about the rules for toxicity studies of phytotherapeutical products. 
National Secretariat for Sanitary Surveillance, Ministry of Health.).

Brasil 2000. Resolução-RDC $n^{\circ} 17$, de 24 de fevereiro de 2000 - Dispõe sobre o registro de Fitoterápicos. Agência Nacional de Vigilância Sanitária, Ministério da Saúde. (Resolution-RDC $n^{\circ} 17$, of February 24th, 2000 - Sets forth about the registration of Phytotherapeutical Products. National Agency for Sanitary Surveillance, Ministry of Health.).

Brasil 2004. $R E n^{\circ} 90$ de 16 de março de 2004 - Determina a publicação do "Guia para a realização de estudos de toxicidade pré-clínica de fitoterápicos", Ministério da Saúde, Agência Nacional de Vigilância Sanitária.

Brito AS 1994. Manual de Ensaios Toxicológicos In vivo, Editora da UNICAMP, Campinas-SP.

Carvalho ACB, Balbino EE, Maciel A, Perfeito JPS 2008. Situação do registro de medicamentos fitoterápicos no Brasil. Rev Bras Farmacogn 18: 314-319.

Dean FM 1963. Naturally Occurring Oxygen Ring Compound', London Butterworths 200-201.

DEF 2000. Dicionário de Especialidades Farmacêuticas, Ed. Jornal Brasileiro de Medicina, Rio de Janeiro.

Hoehne FC 1946. Frutos Indígenas do Brasil, São Paulo, Instituto de Botânica de São Paulo..

Jimbow K 1998. Vitiligo. Therapeutic advances. Dermatol Clin 16: 399-407.

Joseph PK, Rao KR, Sundaresh CS 1989. Toxic effects of garlic extract and garlic oil in rats. Indian J Exp Biol 27: 977-979.

Lapa AJ, Karniol IG, Corrado AP, Ribeiro AB, Melito 1983. I Relatório da Comissão de Ensaios Pré-clínicos e Clínicos. Ribeirão Preto-SP, Relatório da Central de Medicamentos.

Lerner AB, Nordlund JJ 1977. Vitiligo. What is it? Is it important? JAMA 113: 421-422.

Litchfield JT, Wilcoxon F 1949. Simplified method evaluation dose-effect experiments. $J$ Pharmacol Exp Ther 96: 99-113.

Macedo M, Ferreira AR 2004. Plantas medicinais usadas para tratamentos dermatológicos, em comunidades da Bacia do Alto Paraguai, Mato Grosso. Rev Bras Farmacogn 14 (Supl. 1): 40-44.

Malone MH, Robichaud RC 1962. A hippocratic screen for pure or drug materials. Lloydia 25: 320-332.

Martins JEC, Pozetti GL, Sodré MA 1974. Effects of psoralen and bergapten on irradiated skin. Int J Dermatol 13: 124-128.

OECD 1999. Organisation for Economic Co-operation and Development, Guideline 425: Acute Oral Toxicity: Modified Up-and-Down Procedure.

Ortêncio WB 1997. Medicina Popular do Centro-Oeste, $2^{\text {a }}$ Edição, Ed. Thesaurus, Brasília.

Parsad D, Saini R, Verma N 1998. Combination of PUVA sol and topical calcipotriol in vitiligo. Dermatology 197: 167-170.

Pozetti CL 1966. Contribuição ao estudo químico da Alomia fastigiata Benth. Tese. Faculdade de Farmácia e Odontologia, Araraquara.

Pozetti CL 1969. Contribuição ao estudo químico do Brosimum gaudichaudii Trécul. Revista da Faculdade de Farmácia e Odontologia de Araraquara 3: 125-223.

Ribeiro AQ, Leite JPV, Dantas-Barros AM 2005. Perfil de utilização de fitoterápicos em farmácias comunitárias de Belo Horizonte sob a influência da legislação nacional. Rev Bras Farmacogn 15: 65-70.

Sampaio SAP, Castro RM, Rivitti EA 1983. Dermatologia Básica, $3^{\text {a }}$ ed., Ed. Artes Médicas, 212-216.

Silva MIG, Gondim APS, Nunes IFS, Sousa FCF 2006. Utilização de fitoterápicos nas unidades básicas de atenção à saúde da família no município de Maracanaú (CE). Rev Bras Farmacogn 16: 455-462.

Veiga-Junior VF 2008. Estudo do consumo de plantas medicinais na Região Centro-Norte do Estado do Rio de Janeiro: aceitação pelos profissionais de saúde e modo de uso pela população. Rev Bras Farmacogn 18: 308-313.

Vieira IJC, Matias L, Braz-Filho R, Rodrigues E 1997. Um novo fotossensibilizante de Brosimum gaudichaudii. XX Reunião Anual da sociedade Brasileira de Química, Livro de Resumos, 064 Poços de CaldasMG.

Vidal A, Fallarero A, Pena BR, Medina ME, GRA B, Rivera F, Gutierrez Y, Vuorela PM 2003. Studies on the toxicity of Punica granatum L. (Punicaceae) whole fruit extracts. J Ethnopharmacol 89: 295-300.

WHO 1993. World Health Organization Regional Office for the Western Pacific. Research Guidelines for Evaluating the Safety and Efficacy of Herbal Medicines, Manila. 